\title{
Effect of Different Mixture of Molasses and Atella on Growth Responses of Two Year Old Arsi-Bale Rams
}

\author{
Aman G, Girma D, Mieso G, Frehiwot M, Ashebir W, Tesfaye Alemu Tucho and Genet D \\ Adami Tulu Agriculture Research Center, P.O.Box 35, Zeway, Ethiopia
}

\begin{abstract}
The study was conducted at Adami Tulu Agricultural Research Center on two years old Arsi-Bale rams. Twenty four rams were purchased from the Maki, Batu and Bulbula markets. The study was carried out to evaluate the effects of feeding different mixture of molasses and atella on growth responses of two years old Arsi-Bale rams. Four feeding treatments $\left(\mathrm{T}_{1}=\right.$ Grazing $+10 \%$ molasses $+40 \%$ wheat bran $+50 \%$ noug seed cake, $\mathrm{T}_{2}=$ Grazing $+30 \%$ atella $+50 \%$ wheat bran $+20 \%$ noug seed cake, $\mathrm{T}_{3}=$ Grazing $+10 \%$ molasses $+40 \%$ atella $+25 \%$ wheat bran $+25 \%$ noug seed cake and $\mathrm{T}_{4}=$ Grazing $+65 \%$ wheat bran $+35 \%$ noug seed cake) were evaluated during the fattening period. Complete Randomized Block Design was implemented to assign six rams to each of the four treatments. Average daily live weight gains of 81.9, 76.6, 59 and 91.6 grams were recorded for rams in treatments one, two, three and four, respectively. Significant differences in final body weight, total weight gain and average daily weight gains were observed between treatments three and four. With respect to the levels of atella in the rations, comparatively, higher level resulted in lower growth rate of the rams than the lower level. The partial budget analysis indicated positive gross margins for all treatment groups, with higher values for treatment four and lower values for treatment two. Therefore, fatteners can use one of the feed mixtures for two years old ArsiBale rams based on the accessibility and availability of the ingredients to be used to formulate the rations.
\end{abstract}

Keywords: Molasses atella mixture, Arsi-Bale rams, Sheep fattening

DOI: $10.7176 / \mathrm{FSQM} / 90-02$

Publication date:September $30^{\text {th }} 2019$

\section{Introduction}

Ethiopia has above 30 million heads of sheep (CSA, 2017). Beside large population, sheep production is very low. Carcass yield of local small ruminants remained at about $8 \mathrm{~kg}$ per head which was below the East African $(11 \mathrm{~kg})$ and the world (12 kg) average carcass yield (Getahun, 2008). In Ethiopia, the current per capita consumption of meat is $13.9 \mathrm{~kg} /$ year, being lower than the African and the world per capita averages, which are $27 \mathrm{~kg} / \mathrm{year}$ and $100 \mathrm{~kg} /$ year, respectively (Tsigereda et al., 2016).

The traditional livestock fattening practices mostly depend on the natural pasture (Belay and Menale, 2017). Under such systems, livestock production mostly depends on increase of animal numbers rather than targeting higher carcass weight per animal. Productivity increment through increase of animal numbers alone is unlikely to meet the current meat demand of country (Shapiro et al., 2015). Therefore, improving the live weight gain of animals through fattening is an important issue to increase meat production. Livestock fattening is also an emerging sector for employment and income generation for the poor, especially the landless, destitute and widowed women and a hence is a tool for poverty reduction (Zemene et al., 2016).

The live weight gain of local sheep is affected the availability of feeds. To this end, using different feed mixtures is an important issue to increase the meat production in our country. However there is limited information on the use of different mixtures for fattening, particularly, for our local sheep. Hence, this study was conducted to evaluate the effects of different mixtures of molasses and atella on the growth responses of two years old ArsiBale rams.

\section{Materials and Methods Description Study site}

The study was conducted at Adami Tulu Agricultural Research Center, which is located in mid rift valley, at 167 $\mathrm{km}$ from Addis Ababa, at an altitude of $1650 \mathrm{~m}$ above sea level. The agro ecological zone of the area is semi-arid and sub humid with acacia woodland vegetation. The mean annual rain fall of the area is $760 \mathrm{~mm}$. Its mean minimum and maximum temperatures area 12.6 and $27^{\circ} \mathrm{c}$, respectably.

\section{Experimental animals}

Twenty four Arsi-Bale sheep were purchased from the Meki and Bulbula markets of the East Shoa Zone of Oromia Region. Experimental animals were treated for both internal and external body parasites. Purchased rams were kept under quarantine in separate barn and they were treated against internal and external parasites before the commencement of the fattening trial. All experimental rams were randomly assigned to one of the four treatment groups.

Experimental feeds

The following four different feed mixtures were used: 
$\mathrm{T}_{1}=$ Grazing $+10 \%$ molasses $+40 \%$ wheat bran $+50 \%$ noug seed cake

$\mathrm{T}_{2}=$ Grazing $+30 \%$ atella $+50 \%$ wheat bran $+20 \%$ noug seed cake

$\mathrm{T}_{3}=$ Grazing $+10 \%$ molasses $+40 \%$ atella $+25 \%$ wheat bran $+25 \%$ noug seed cake

$\mathrm{T}_{4}=$ Grazing $+65 \%$ wheat bran $+35 \%$ noug seed cake

Feeding of experimental animals

After 14 days of adaptation period, rams were provided with their respective supplementary feed according to their requirements at the rate of $2.5 \%$ of their body weight. The amount of feed given to each animal was adjusted every two weeks during the fattening period. Each dietary treatment was offered twice daily (half in the morning and half in the afternoon after 8 hours grazing) for the respective groups of animals. All the experimental rams were individual fed on their corresponding rations for during fattening period.

Growth performance measurement

$$
\begin{aligned}
& \mathrm{ADW}=\frac{(F B W-I B W)}{\mathrm{D}}, \\
& T W G=F B W-I B W
\end{aligned}
$$

Where: $\quad \mathrm{ADG}=$ Average daily weight gain, $\mathrm{TWG}=$ Total weight gain, $\mathrm{FBW}=$ Final body weight, $\mathrm{IBW}=\mathrm{Initial}$ body weight and $\mathrm{D}=$ Total of fattening days

\section{Economic returns on rams fattening}

All variable costs incurred in conducting the trial were recorded. Total variable costs such as animals purchase, transportation, feeds, labor and veterinary costs were included in the partial budget analysis. The gross output/revenues were obtained from the estimated prices of the rams at the end of the fattening periods which was done by the help of persons who have enough knowledge on prices of fattened animals. The fixed costs incurred for feeding animals were not included in cost benefit analysis.

\section{Statistical analysis}

Data on live weights and carcass parameters were analyzed using general linear model (GLM) of Statistical Analysis System (ver. 8). The estimated least squares means were separated using the Duncan's Multiple Range Test at $P<0.05$.

\section{RESULT AND DISCUSSION}

\section{Effects of molasses and atella mixtures on growth performance of rams}

Effects of different mixture level of molasses and atella on growth performance of rams are indicated in Table 1. The current study showed that significant difference in final body weight, total weight gain and average daily weight gains between animals fed treatments three and four. Animals in treatments four $(65 \%$ wheat bran $+35 \%$ noug seed cake) have the highest mean values of the above mentioned parameters as compared to those in treatments two, one \& three. No statistically significant differences in final body weight, total and average daily weight gains among rams fed treatments one, two and three. However, rams fed on feed mixture one (mixture of molasses with concentrate) were attained the higher body weight gain as compared to those fed on feed mixture groups two and three. The rams fed the concentrate feeds $\left(\mathrm{T}_{4}\right)$ were attained higher average daily weight gain than the others groups. Other study conducted at Adami Tulu Agiculture Research Center indicated that yearling ArsiBale rams fed on wheat bran and cotten seed cake had attained 104.7 g/day (Aman et al., 2019).

Table 1: Effect of different mixture level of molasses and atella on growth performance of rams

\begin{tabular}{lllll}
\hline Treatments & IBW $(\mathrm{kg})$ & FBW $(\mathrm{kg})$ & $\mathrm{TWG}(\mathrm{g})$ & ADG $(\mathrm{g})$ \\
\hline $\mathrm{T}_{1}$ & 24.2 & $30.3 \pm 0.8^{\mathrm{ab}}$ & $6142.8 \pm 384.7^{\mathrm{ab}}$ & $81.9 \pm 5.1^{\mathrm{ab}}$ \\
$\mathrm{T}_{2}$ & 24 & $29.7 \pm 0.74^{\mathrm{ab}}$ & $5750 \pm 359.9^{\mathrm{ab}}$ & $76.6 \pm 4.8^{\mathrm{ab}}$ \\
$\mathrm{T}_{3}$ & 23.9 & $28.4 \pm 0.8^{\mathrm{a}}$ & $4428.6 \pm 384.8^{\mathrm{a}}$ & $59 \pm 5.1^{\mathrm{a}}$ \\
$\mathrm{T}_{4}$ & 24.21 & $31 \pm 0.75^{\mathrm{b}}$ & $6875 \pm 359.9^{\mathrm{b}}$ & $91.6 \pm 4.8^{\mathrm{b}}$ \\
\hline$a, b,=$ Values in a column followed by different superscripts & are significantly different $(P<0.05)$
\end{tabular}

The rams fed the higher percentage of attela mixed with molasses, wheat bran and Noug seed cake were attained lower total weight gain than the others groups. However weight gains of rams fed $\mathrm{T}_{3}$ are relatively similar to Abera sheep (65 g/day) that supplemented concentrate feed 100 gram per day (Mereset, 2016). Similarly study conducted at Debre Zeit Agricultural Research Center (Getahun, 2014) also indicated that Black Head Ogaden sheep which fed teff straw ad-libtum and 450 gram concentrate per day have average daily weight gain of 65.2 $\mathrm{g} /$ day. Atella is byproduct of traditional tella and considered as non-conventional livestock feeds (Solomon, 2007). Quality of Atella might not consistency because it matters by ingredients, time and skills of makers. Rams fed higher level atella mixture (T3) were gained lower body weight than others treatment. This may correlate to the level of protein since it has low protein and higher energy nutrient than all treatments. 
Partial budget analysis

Table 2: Partial budget analysis of fattening two years old Arsi-Bale rams

\begin{tabular}{llllll}
\hline List of items & T1 & T2 & T3 & T4 & Overall \\
\hline Feeds costs per ram (ETB) & 198 & 185.65 & 150.25 & 210.5 & 186.1 \\
Purchasing price per ram (ETB) & 1400 & 1400 & 1400 & 1400 & 1400 \\
Labor cost per ram (ETB) & 109.5 & 109.5 & 109.5 & 109.5 & 109.5 \\
Veterinary cost per ram (ETB) & 25 & 25 & 25 & 25 & 25 \\
Total variable coast per ram (ETB) & $\mathbf{1 7 3 2 . 5}$ & $\mathbf{1 7 2 0 . 1 5}$ & $\mathbf{1 6 8 4 . 7 5}$ & $\mathbf{1 7 4 5}$ & $\mathbf{1 7 2 0 . 6}$ \\
Total gross output per ram (ETB) & 2100 & 2100 & 2000 & 2200 & 2100 \\
Gross margin per ram (ETB) & 367.5 & 379.85 & 315.25 & 455 & 379.4 \\
\hline Total gross margin (ETB) & $\mathbf{2 2 0 5}$ & $\mathbf{2 2 7 9 . 1}$ & $\mathbf{1 8 9 1 . 5}$ & $\mathbf{2 7 3 0}$ & $\mathbf{2 2 7 6 . 4}$ \\
\hline
\end{tabular}

ETB: Ethiopian Birr

Partial budget analysis of fattening two years old Arsi-Bale rams are presented in Table 2. Experimental rams fed atella mixture have total less variable cost than others treatment groups due to less feed cost per rams. The atella purchased from the local tella maker women house which found near the study area. Even though high variable cost was incurred in treatment four (rams that fed wheat bran and noug seed) gross profit margin also higher than rams fed molasses and atella mixture. The Arsi-Bale rams fed treatment four were gained more body weight during fattening period. The body weights of animals may correlate to selling price of rams.

\section{Conclusion and Recommendation}

The twenty four Arsi-Bale rams were fed on different of Atella and molasses mixture level for 75 days. Rams fed treatment four have attained higher body weight gains followed by treatment one and two. Therefore, fatteners can use one of the $T_{4}, T_{1}$ and $T_{2}$ treatments based on the dietary feeds available to fatten two years old Arsi-Bale rams. Furthermore, study needs to know the optimum effects of atella and molasses mixture level in the feed rations. The partial budget analysis indicates all groups Arsi-Bale rams were allocated to treatments have positive gross margin. Therefore, fatteners can use one of treatments based on the feeds available to fatten two years old Arsi-Bale rams for local markets.

\section{ACKNOWLEDGMENTS}

The authors are grateful to Oromia Agriculture Research Institute, for funding the experiments. We would like to extend our appreciation to Adami Tulu Agriculture Research Centre for technical support and for enabling us with a conducive working environment in conducting the study.

\section{References}

Aman Gudeto, Mieso Guru, Tesfaye Alemu, Ashebir Worku, Genet Dadi (2019). Evaluation of different feeding options for yearling Arsi Bale sheep rams to attain export market body weight. Basic journal of Agricultural Science and Review ISSN 2315-6880 Vol.7 (4), pp.35-39

Belay Zeleke, Minale Getachew, (2017). Traditional Cattle Husbandry Practice in Gamo Gofa Zone, Southern Western Ethiopia. Arba Minch University College of Agricultural Sciences, P.O.Box 21, Arba Minch Ethiopia

Central Statistical Agency (CSA) (2017). Agricultural sample survey, Report on livestock and livestock characteristics, 2017, Addis Ababa, Ethiopia.

Getahun L (2008). Productive and Economic performance of Small Ruminant production in production system of the Highlands of Ethiopia. PhD dissertation, University of Hohenheim, Stuttgart-Hoheinheim, Germany.

SAS (2002). User's Guide: - Statistics (Version 8) SAS Institute. Inc., Cary, NC

Shapiro B, Getachew G., Solomon D., Asfaw N., Kidus N., Gezahegn A., Henok M., (2015). Ethiopia livestock master plan, Roadmaps for growth and transformation.

Solomon Demeke, (2007). Comparative nutritive value of Atella and industrial brewers grains in chicken starter ration in Ethiopia. Livest. Res. Rural Dev., 19 (1)

Tsigereda Fekadu, Mengistu Urge, Emebet Moreda, (2016). Assessment of Traditional Cattle Fattening Practices in Hararghe Highland Parts of Ethiopia. Ethiopian Institute of Agricultural Research, P.O.Box 32, Debre Zeiet, Ethiopia

Zemene Worku, Samuel Tilahun, Taye Tolemariam, Worku Jimma (2016). Assessment of the Prevailing Cattle Fattening Practices in Jimma Zone. Global Veterinaria. 17 (2):105-113. 